This item was submitted to Loughborough's Research Repository by the author.

Items in Figshare are protected by copyright, with all rights reserved, unless otherwise indicated.

\title{
Emotional journeys in game design teams
}

PLEASE CITE THE PUBLISHED VERSION

http://dx.doi.org/10.4018/978-1-60960-567-4.ch014

PUBLISHER

IGI Global

VERSION

VoR (Version of Record)

\section{PUBLISHER STATEMENT}

This work is made available according to the conditions of the Creative Commons Attribution-NonCommercialNoDerivatives 4.0 International (CC BY-NC-ND 4.0) licence. Full details of this licence are available at: https://creativecommons.org/licenses/by-nc-nd/4.0/

\section{LICENCE}

CC BY-NC-ND 4.0

\section{REPOSITORY RECORD}

Stacey, Patrick K., and Joe Nandhakumar. 2019. "Emotional Journeys in Game Design Teams". figshare. https://hdl.handle.net/2134/22877. 


\section{Business, Technological, and Social Dimensions of Computer Games:}

\section{Multidisciplinary Developments}

Maria Manuela Cruz-Cunha

Polytechnic Institute of Cávado and Ave, Portugal

Vitor Hugo Costa Carvalho

Polytechnic Institute of Cávado and Ave, Portugal

Paula Cristina Almeida Tavares

Polytechnic Institute of Cávado and Ave, Portugal 
Senior Editorial Director:

Kristin Klinger

Director of Book Publications:

Julia Mosemann

Editorial Director:

Lindsay Johnston

Acquisitions Editor:

Erika Carter

Production Editor:

Sean Woznicki

Typesetters:

Print Coordinator:

Keith Glazewski, Natalie Pronio, Jennifer Romanchak, Milan Vracarich Jr.

Cover Design:

Jamie Snavely

Nick Newcomer

Published in the United States of America by

Information Science Reference (an imprint of IGI Global)

701 E. Chocolate Avenue

Hershey PA 17033

Tel: 717-533-8845

Fax: 717-533-8661

E-mail: cust@igi-global.com

Web site: http://www.igi-global.com

Copyright (C) 2011 by IGI Global. All rights reserved. No part of this publication may be reproduced, stored or distributed in any form or by any means, electronic or mechanical, including photocopying, without written permission from the publisher. Product or company names used in this set are for identification purposes only. Inclusion of the names of the products or companies does not indicate a claim of ownership by IGI Global of the trademark or registered trademark.

\section{Library of Congress Cataloging-in-Publication Data}

Business, technological, and social dimensions of computer games:

multidisciplinary developments / Maria Manuela Cruz-Cunha, Vitor Hugo Carvalho

and Paula Tavares, editors.

p. cm.

Includes bibliographical references and index.

Summary: "This book is a collection of the most recent developments in all

areas of game development, encompassing planning, design, marketing, business

management, and consumer behavior"--Provided by publisher.

ISBN 978-1-60960-567-4 (hbk.) -- ISBN 978-1-60960-568-1 (ebook) 1. Video

games industry. 2. Video games--Design. 3. Video games--Social aspects. I.

Cruz-Cunha, Maria Manuela, 1964- II. Carvalho, Vitor Hugo, 1979- III. Tavares,

Paula, 1973-

HD9993.E452B87 2011

338.4 '77978--dc22

2011012885

British Cataloguing in Publication Data

A Cataloguing in Publication record for this book is available from the British Library.

All work contributed to this book is new, previously-unpublished material. The views expressed in this book are those of the authors, but not necessarily of the publisher. 


\title{
Chapter 14 Emotional Journeys in Game Design Teams
}

\author{
Patrick Stacey \\ Imperial College London, UK \\ Joe Nandhakumar \\ University of Warwick, UK
}

\begin{abstract}
There is little research into the emotional dimension of creative industry personnel, such as computer game designers, and how emotions relate to their creative practices and work-related events. Such socioemotional work is the focus of this chapter. There is a practice-centered relevance to this topic too - it is reported that there exists a poor quality of life in many global game studios. Given our deficient knowledge of emotions in computer game development, and the practical resonance of this topic, our key research question is: What emotions, creative practices and work-related events characterize emotional journeys in computer game design teams, and how do these characteristics inter-relate? To explore and answer this research question, we draw on an in-depth field study of a computer games studio in Singapore. The chapter offers a theory of emotion-mediated improvisation as a coping model for the tumultuous emotional journeys that game developers endure.
\end{abstract}

\section{INTRODUCTION}

It is widely held in the creativity literature that being 'well' and feeling 'good' is fundamental to being creative: "The results indicate that positive affect relates positively to creativity in organizations and that the relationship is a simple

DOI: 10.4018/978-1-60960-567-4.ch014 linear one." (Amabile et al, 2005:p.367) Despite the voluminous research that connects positive emotions to creativity (e.g. Amabile et al, 2005; Bartel and Saavedra, 2000; Vosburg, 1998; George and Zhou, 2007), there is little research into the emotions of creative industry personnel, such as computer game designers. There are studies of the social practices of designers (e.g. Cross 1994) but little or no understanding of their emotions 
and how these relate to their creative practices and work-related events. Such socioemotional work life is the locus of this chapter. There is a practice-centered relevance to this topic too; in 2004 emotional quality of life (QoL) became an important topic in discourses on computer game development. That year the International Game Developers Association (IGDA) released the results of its first global survey, which found poor QoL in global game studios on account of impossible deadlines, peer pressures and lack of concern and support for the family unit, leading to early departures to rival industries. In April 2009 Develop Magazine conducted a similar survey of QoL which supported the 'impossible deadlines' facet which respondents referred to as 'crunch', or "the industry's dirty secret." ${ }^{1}$ Furthermore, management "sociopathy" was highlighted, i.e. producers and others exhibiting anti-social behavior towards their team members with little regard for their feelings or emotional well-being. And yet, research posits that being 'well' and feeling 'good' is fundamental to being creative. Focusing on this topic is therefore timely for both scholarship and practice.

Given our deficient knowledge of emotions in computer game development, our key research question is: What emotions, creative practices and events characterize emotional journeys in computer game design teams, and how do these characteristics inter-relate? This is important given the concern over emotional well-being in computer game studios around the world ${ }^{2}$, and its potential threat to the economic contribution the computer games industry makes. For example, according to the UK's National Endowment for Science, Technology and the Arts (NESTA), the industry contributes $£ 1$ billion to the GDP - equivalent to the size of the UK's film industry. Therefore, our research has potentially useful implications for game industry organizations, i.e. means by which they can improve their emotional well-being, enhance their creative efficacy and protect their economic well-being too.
The rest of the chapter is structured as follows: Firstly, we impart a framework for theorizing about the emotions, creative practices and events that characterize emotional, well-being journeys in computer game design teams, and their inter-play. In doing so, we show the pertinence of drawing on Giddens' stratification model of the agent as a means of conceptualizing the links between these characteristics. We also refer to literatures concerning software development and demonstrate that such approaches fail to take account of developers' inner-life. Secondly, we present data drawn from an in-depth field study of a computer games studio in Singapore, which highlight the above three characteristics of such journeys. Thirdly, we analyze the data using the Giddensian lens, and, fourthly offer a theory of emotion-mediated improvisation as a coping model for the tumultuous emotional journeys that game developers endure.

\section{THEORETICAL FRAMEWORK}

We commence this section by referring to literatures concerning software development, to demonstrate that there are few frameworks in the field of IS that address the emotional journeys and needs of developers.

\section{Related IS Development Research}

Traditionally, structured software methodologies have been advocated as a means of making the development process smoother and controlled (Nandhakumar and Avison 1999). However, they offer limited guidance when unexpected, emoting challenges emerge during the software development process. Agile methods such as eXtreme Programming (XP) (Beck 1999) and the Rational Unified Process (RUP) (Kruchten, 1996) have been proposed as more responsive approaches to software development. However, it is debatable just how distinct from traditional approaches some of these really are (Paulk 2001). 
Some Agile authors express desires which are reminiscent of methodology authors: "we want to do everything we must do to have a stable, predictable software development."(Beck, 1999); Agile is not anti-methodology (Highsmith 2002). However, when the process breaks down, due to a developer resigning for instance, a plan is of little use and arguably developers are left to join-the-dots and improvise. To understand how they improvise necessitates detailed interpretive field studies of IS development (ISD), such as the ones by Curtis, Krasner et al. (1988), Jones and Walsham (1992) and Brown, Stacey et al. (2008). Such studies address ISD as a situated social process (Hirschheim, Klein et al. 1995), bringing into focus the "everyday life" of software developers and the emergent social and political challenges developers face.

An abundance of software development contexts have already been studied such as executive information systems (Nandhakumar and Jones 1997), defense systems (Humphrey et al. 1991), financial systems (Guinan et al. 1998), web browsers (Cusumano and Yoffie 1999) and student information systems (Newman and Noble 1990). By comparison, computer games development has thus far received limited attention, with the exception of Baba and Tschang (2001), Holmström (2001) and Tschang (2007). Furthermore, current research themes in the computer games field focus on specific activities in the process, particularly game design. This stream of research discusses a variety of design techniques, like scenarios, body storming, paper prototyping, rapid prototyping, theatrical techniques of improvisation (Clanton, 1998; Bjork et al., 2002; Johnson and Wiles, 2003), simulation (Kaneva and Sugiyama, 1998), cuisinart (Rouse III, 1999), and play environments such as mixed reality (Cheok et al., 2002). A second stream of game research is artificial intelligence, which tries to improve the intelligence of the computer-opponent to enrich single-player gaming (Schaeffer and Jaap van den Herik, 2002).
Development approaches in computer games and software generally do not therefore take account of the emotional aspect of development. Beyond studies of methods, there are only a handful of studies on emotion in ISD, which we now turn to.

\section{Emotions, Moods and Inner-Life}

Little scholarly attention has been afforded to the concept of emotion in ISD (throughout this paper we assume emotion has an equivalent meaning to moods, and inner-life). This is surprising given the numerous studies that have drawn attention to the political and conflictual nature of the ISD process, such as Robey and Markus (1984), Wastell (1996), and Sawyer (2001). Exceptions to the rule are: Wang and Ahmed (2002), Ciborra (2002) and Nelson (2005), however only Nelson's contains empirical data. But, what are emotions anyway? Emotions are reactions to a certain situation, based on a person's interpretation (Wang and Ahmed, 2002:p1291). This concurs with appraisal theory as expounded in the psychology literature: "the basic idea then is that our emotional reactions depend not on the specific characteristics of stimulus events, but rather on the way that we interpret and evaluate what is happening to us (appraisal)" (Parkinson et al., 2005:p.6). Emotions therefore tend to have an identifiable cause or object to which they are attached, such as the actions of others in a social setting (Callahan and McCollum, 2002; Scherer et al., 1986). For instance, when we are playing computer games, play is emotional: "[play is] a free and voluntary activity, a source of joy and amusement" (Huizinga, 1970:p26). And joy is "a sense of pleasure plus the urge toward exuberance and contact-seeking" (Frijda, 1988:p351). Therefore, emotion is directly related to human social action and they inter-play. For instance: "The root of the [emotional] problem often lies with longstanding and deeply embedded ground rules or habits that govern the group. We call those rules [social] norms" (Goleman et al., 2002:p223). Or, 
in structuration theory, the reproduction of social practices or the persistence of routines as offering their reflexive perpetrators a degree of ontological security (Cassell, 1993). The inter-play between emotion and action is therefore not a one-waystreet; emotions are not just reactions, but they are triggers for action too - they can unwittingly push us along a particular course (Fineman, 2003). For example, negative moods like embarrassment can have positive effects by provoking people to repair broken relationships (Bagozzi, 2003).

In summary, studies demonstrate that emotion both provokes and responds to human social action and events. And, that these characteristics of emotional journeys are mediated by interpretations or evaluations of occurrences, as per appraisal theory (see Figure 1).

We now discuss further another characteristic of emotional journeys: action. In this chapter we are particularly interested in one kind of action: improvisation.

\section{Improvisation and Agency}

Perhaps one of the greatest advocates for studying the link between emotions/moods and action is Ciborra. He said: "What is missing from the situated action literature is precisely an enquiry into the situation of the actor, specifically his moods. Only by bringing back into the picture the situation of the actor, those fleeting personal circumstances (captured by the term 'mood'; in Latin, affectio), and not only the emerging environmental

Figure 1. Appraisal perspective of emotions

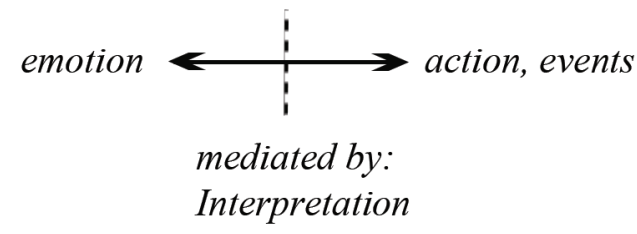

circumstances can we get a fresh understanding of improvisation" (Ciborra 2002:p160). Indeed, improvisation is situated and emergent (Ciborra 2002), occurring at the meeting point of thought and action, at a moment in time (Levi-Strauss, 1966; Orlikowski 1996; Ciborra 1999); it is extemporaneous. This is particularly noticeable during emergencies where capable individuals and teams improvise life-saving solutions out of chaos (Ciborra 1999). Such solutions also reflect the role of local conditions or social and physical contexts in enabling and constraining improvisation (Nandhakumar and Jones 1997). How and whether contexts enable or constrain partly depends on the capability of improvising "agents" in the situation; some may feel there is nothing they can do whereas others may leverage context for action. Just because things have been "so" does not mean they should continue as such, "the seed of change is there in every act which contributes towards the reproduction of any 'ordered' form of social life” (Giddens 1993:p108). In social theory this concept is examined within human agency. For Giddens, this has much to do with an agent's capability or power to take action in a situation. For instance, when one's emotional 'state' is challenged by the dynamics of computer game work. In this chapter then, we think of and analyze improvisation in terms of human agency. Specifically-we draw on the elements of Giddens' Stratification Model of the Agent to conceptualize how developers respond to emotional challenges.

Ciborra might say that this model is only useful up to a point, since it has been criticized for omitting emotions and moods in explaining an agent's capability to act (Bailyn 2002).

Giddens merely acknowledges that an agent's emotions are connected to their motivation to act: "The connection of motivation to the affective elements of personality is a direct one, and is recognized in everyday usage; motives often have 'names' - fear, jealousy, vanity, etc." (Cassell, 1993:p92). However, he does not develop this further nor incorporate it into his stratifica- 
Figure 2. Giddens'Stratification Model of the Agent (Giddens, 1984)

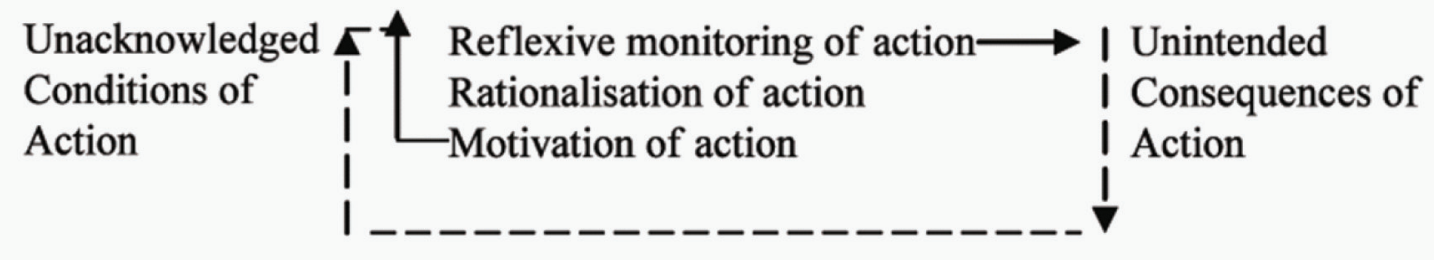

tion model of the agent. We therefore address this deficiency in this chapter by showing how the model can be extended with emotion and the related appraisal theory concept of interpretation. Therefore an extended stratification model of the agent is offered as a means of conceptualizing the emotional journeys of computer game developers.

\section{RESEARCH SETTING AND APPROACH}

We conducted an in-depth field study of a computer games studio in Singapore. We decided to pursue a case study in Singapore because the games industry is still taking shape there. The carving out of this industry is a response to the economic and social crises Singapore has faced, such as Asian Financial Crisis (1997) and SARS (2003). Three agencies are involved in cultivating this industry; the Media Development Authority (MDA), the Infocomm Development Authority (IDA) and the Singapore Economic Development Board(SEDB). The MDAestablished the Media21 initiative, "to increase the GDP contribution of the media cluster from the current 1.56 per cent to 3 per cent...[and] nurture home-grown media enterprises". The SEDB persuaded internationally renowned games companies to setup fully operational offices in Singapore, such as Lucasfilm (US), Koei (Japan) and Genki (Japan). The IDA focused on the deployment and distribution of online games through initiatives such as Games Bazaar.
The research approach adopted in this study is interpretive (Walsham 1993) involving a collection of detailed, qualitative data on the game development process in its context. We conducted twenty-four interviews with developers at a small game studio in Singapore called CGS (a pseudonym) to try to understand their development process and the unforeseen challenges they face. CGS was founded in March 2003 with a development team of twenty staff or so. Even though the company's main operations are in Singapore, it has developed numerous games in association with studios in France, Italy and Ireland, and distributed them throughout Europe. When we visited their premises the meeting room was filled with antique Indonesian furniture and mythical games merchandise hung on the walls. In the engineers' office the walls seemed to reflect their female fantasies, and there were various physical games like table football, and basketball in the artists' office; a working environment that seemed conducive to long hours of work. The company focused on producing computer games for mobile phones although they had produced a small number for the PC format too.

\section{Data Collection and Analysis}

This study employed interviews as the primary means of data collection. Between January 2004 and September 2005 we conducted twenty four semi-structured interviews, which were really guided conversations, i.e. at times the interviewee was given or took the "reins" of the conversation 
as they talked about games projects they had been involved with. However, given these were semistructured interviews, we prepared an interview guide prior to each conversation so as to ensure our key topics of interest were explored. We asked each interviewee to talk about past projects, to recount them as stories so we could understand what had happened. We then asked them to talk about unexpected events which occurred during the lifetime of the project, and how they dealt with them. By getting inside the world of those generating it (Rosen 1991), particularly through face to face contact (Lofland 1995) we overcame the problem of possibly modified, and therefore unrepresentative actor behavior that is common in cross-sectional studies. People cannot behave in a modified manner for long because, "they are limited by culture, custom, natural impulses, habits, and longstanding patterns of interaction" (Ellis, 1995:p93). Moreover, this is an apposite means of researching emotion, even though a popular approach to researching emotion is through quantitative means (e.g. Diener, 2000; Nelson, 2005). However, Nelson (2005) admits that the valencing of interviewee emotions according to organizational situations, placed limits on her research, and calls for more observation of emotions in action (p7). Bearing this in mind we looked for 'emotional clues'. We did this by noting responses to actions and practices recounted in terms of how the interviewees expressed themselves, such as seeming frustrated. Although I preferred not to provoke them, sometimes I did ask how an event made them feel, noting the meanings they assigned to those actions (as per appraisal theory), practices and events.

Table 1 exhibits the people interviewed and their position at CGS.

We adopted an interpretive approach to collecting and analyzing the interview data; we attempted to understand game development challenges by trying to make sense of the meanings that each interviewee expressed with respect to the development process and emergent events.
We used nVivo (a Computer-aided Qualitative Data Analysis Software) to help organize and analyze the data.

For the analysis we drew on Giddens' stratification model of the agent as a lens, the elements of which were used as analytical codes. Initially we coded textual "chunks" - words, phrases, sentences, passages - simply as events and actions, i.e. the interviewees' descriptions of what they did in the stories they recounted to us. We then "unpacked" the actions into the elements of Giddens' stratification model of the agent, e.g. reflexive monitoring, rationalization, and motivation. Giddens' Structuration theory (Giddens 1984), which incorporates his ideas on human agency, has been widely used in the field of IS and is valuable in understanding IS phenomena (Jones and Karsten 2003). We were therefore confident this approach would yield interesting research results.

In addition, the moods of the interviewees were too "loud" and too recurrent to ignore. This was noticeable both during and after the transcription process, i.e. from hearing and "reading" the voices of the interviewees. For example, the passage "you better get someone local right? You can get him out and meet him up so can have a better explanation or communication, rather than overseas, because how are you going to contact him if he really disappears?"; the interviewee was obviously worried about working in a team where some of the members were based overseas. We began to

\section{Table 1. The interviewees}

\begin{tabular}{|l|l|l|}
\hline Alf & John & Gayle \\
\hline $\begin{array}{l}\text { Managing } \\
\begin{array}{l}\text { Director } \\
\text { In his mid }\end{array}\end{array}$ & $\begin{array}{l}\text { Project Manager/ } \\
\text { Programmer } \\
\text { In his late twen- } \\
\text { ties }\end{array}$ & $\begin{array}{l}\text { Artist } \\
\text { In her early twenties }\end{array}$ \\
\hline Mac & Andy & Mike \\
\hline $\begin{array}{l}\text { CG Program- } \\
\text { mer cum artist } \\
\begin{array}{l}\text { In his late } \\
\text { twenties }\end{array}\end{array}$ & $\begin{array}{l}\text { Programmer } \\
\text { In his late twen- } \\
\text { ties }\end{array}$ & $\begin{array}{l}\text { Programmer } \\
\text { In his early twenties }\end{array}$ \\
\hline
\end{tabular}


differentiate between emotions/moods, such as "anxiety", "desperation" and "giving up" whilst examining their association with other codes that related to elements of agency such as reflexive monitoring. The theory developed in this study therefore represents bottom-up conceptualization, although during the process we referred to our framework too, as per Strauss and Corbin (1998).

\section{CASE DESCRIPTION}

We present four narratives relating to four challenges the developers faced during the lifetime of their games projects. It was not always possible for all interviewees to discuss the same project however due to the mobility of staff at CGS. For confidentiality reasons, all the interviewees have been given pseudonyms.

\section{Jacky and Team Walk Out}

When the Media Development Authority of Singapore (MDA) advertised its funding scheme in the press, Alf, an entrepreneur and founder of CGS, pitched his game idea to them and successfully garnered their funding. He and his team began to work on the concept for the game for which MDA gave them five months. On the team was Jacky, who was also the chairman of the Animé Club and had his own artists who were already working on a futuristic animation series. Alf suggested merging their ideas but Jacky did not want to since he had his own animation team and concept already. Jacky shared these ideas with Alf and they decided that Jacky would work on an animation series whilst Alf would produce a PC game based on these ideas. After a month or so into the production phase they began discussing how to share the intellectual property. Alf was surprised when this led to a disagreement and Jacky renouncing their partnership and Jacky's staff "walking out". Although this was a serious blow to the project since the game ideas were
Jacky's, Alf did not want to give up, particularly since he had already made a commitment to MDA. Alf persevered and had to decide whether to come up with a completely new game idea or continue with what he had so far but alter the storyline. He decided to do the latter and the game Beyond Event Horizon began to take shape. On reflection, Alf said he was glad that there had been a parting of ways because it became clearer and easier to maneuver. As things started moving again, his senior 3D artist was poached by a US game company. After this second setback Alf decided to coordinate the art team himself, which he described as "a nightmare". However, he mobilized an "army" of freelance 2D and 3D artists. In the end the project was deemed a success; they were invited to Austin, Texas in the US to pitch to a publishing company.

\section{An Image-Artist's Personal Tragedy}

Gayle had to work with an image artist during a mobile role-playing game project. The image artist was in his late thirties and based in the US. She relied on email to communicate and share artwork with him. This led to confusion when the image artist did not e-deliver his work by the agreed date. After a protracted period of silence, it emerged that he had been hospitalized due to a heart attack. This broke the rhythm and momentum of development at CGS, "the thing is they cannot give us a direct reply, they cannot give us a prompt reply", she said, using "they" to refer to overseas artists generally as we discussed this event. She was frustrated in spite of the unfortunate nature of the reason for the breakdown, even though the image artist subsequently introduced CGS to a substitute artist to continue his work. Alf's response to the personal tragedy event was more nuanced. When it occurred, he felt desperate and stressed because the image artist had been leading the art direction on the project. However, this also pushed him to become more ambitious in his talent search; he contacted internationally acclaimed 
Dungeons and Dragons designer Todd Lockwood, as well as renowned cartoonists at Marvel comics and DC comics. Todd Lockwood introduced Alf to a substitute artist (this was different to Gayle's story who had told us that it was the infirmed artist that introduced the replacement artist).

\section{A Date with Microsoft}

Andy talked us through the development of a mobile war game he had almost finished. This was a contract game, i.e. a customer in Ireland had asked for the game, so the concept was already set. Alf, the game designer, came up with a rough draft of a design document that outlined what the game would look like, the game play, the graphics and the storyline. Andy had a quick look at the document to get a rough understanding of what was required, and then asked the client if there was anything on the market similar to what he wanted. Andy said that if there was an existing game on the market, then he could use this as a template and gain a better understanding of what the client wanted. So, instead of having a scenario after a few months of, "this is not what I want, this is not the look I want.", and having to start all over again, he tried to prevent misunderstanding and clarify the vision for the game as early as possible. Andy said he had been in this situation too many times before. Having settled these issues and made some headway after one month into the production phase, Alf told him the client now needed a working demo completed in a few weeks. The client had been given the opportunity to meet with Microsoft's Mobile Division in Ireland and they wanted to show them the demo. So instead of finishing in three months Andy now rushed to implement some of the bells and whistles, such as sound effects, within two months. Andy told us how much he disliked midway changes and he had gone to great lengths to avoid any surprises. He had not anticipated and did not welcome this kind of surprise however; the bringing forward of the deadline as opposed to a change in the requirements. Given the opportunity to have his work seen by Microsoft seemed a motivating factor for him however, and rather changed his tune.

\section{The Lead Programmer Leaves}

Richard left CGS after delivering a Kung Fu fighting game, at which point Mac became depressed and retreated from teamwork. He said he was not sure what was going on, that his work was "pretty independent" of everything else, and that he was not acquainted with the actual work flow within the projects anymore. Mac also talked about how roles used to be organized at CGS when Richard was still around, "we delegated certain roles so we know what actually each other is doing." Richard's departure had left him feeling fed-up because aspects of the development process such as documentation had broken down: "I mean, like now, I'm just drawing these days and I'm really not concerned about the other aspects anymore (sardonically put).", and "I don't care what happens". Richard's exit affected John differently. As opposed to retreating, he had been thrown in with full programming responsibility for three upcoming projects. This was "not something enjoyable", he said, with respect to high rate of work he was experiencing. However, despite the initial stress he expressed to us, he found the first project, developed for a Korean car company, enjoyable; he thought it was a "rush" in the sense of rising to the challenge. Given he only had one month to develop the racing game with the assistance of two artists, he evaluated game engines that would spring-board development. A few years ago he had already come across one called Torque. At that time he did not know what to do with it so he just put it aside but kept it in view. He liked Torque as the source code was provided for the engine, so if anything broke down or there were features he wanted to implement which were not currently available he could do so. Most of the time however, he made use of the scripts that came along with the starter-kit. Various bugs associated 
with the engine arose during the course of project, but through trial and error and "hacking" he and his team were able to surmount them.

\section{ANALYSIS}

The above provided a set of narratives relating to unforeseen development situations. We now provide an initial 'reading' or analysis of the case data by drawing on the language of Giddens' stratification model of the agent.

\section{Jacky and Team Walk Out}

Jacky and his team's departure from CGS led to the breakdown of established routines, and resulted in the incumbents losing their sense of security, or using Giddens' phrase, a loss of ontological security. However, Alf's rationalization for getting the project "back on track" was two-fold; he had a sense of duty to since the Media Development Authority was funding the project, and also the project excited him. His motivation for steering back the project was therefore linked to his feelings of excitement, loyalty and obligation. These feelings provoked him to adjust his reflexive monitoring so as to identify and draw on new rules and resources that would support his improvisations, i.e. modifications to the game's story and concept, which were originally provided by Jacky. Faced with another unexpected challenge - the resignation of the lead $3 \mathrm{D}$ artist and some of his colleagues - Alf took over the reins of lead artist. Through his continuous monitoring of contexts of human resources he assembled a new team of artists. He would not give up. His capability to act and to overcome was related not just to his ability to monitor and mobilize his contexts however, but to his emotional attachment to the project; his motivation was emotional.

\section{An Image-Artist's Personal Tragedy}

When Gayle learned about the image-artist's heart attack and his subsequent departure from CGS, she experienced a loss of ontological security. She attributed the consequences of the personal tragedy to a reliance on talent from overseas, the very thought of which seemed to make her anxious, "you better get someone local right? You can get him out and meet him up so can have a better explanation or communication, rather than overseas" Even before this episode, she was experiencing ontological insecurity since Alf brokered the emails between Gayle and the image artist. Alf as broker meant she had to trust him to relay the emails to and fro, thereby introducing another level of uncertainty and anxiety into her working practices. The ambiguous nature of the unit of monitoring made it challenging for Gayle to track social interactions, i.e. the image artist seemed to be at times "online" and at others "offline", detached. She coped with her frustration and insecurity by perhaps rationalizing that she needed to be somewhat more independent; a desire for freedom. So she adjusted her reflexive monitoring and began looking for inspiration and direction elsewhere. She decided to consult other mobile games, Dungeons and Dragons, mythical novels and Magic the Gathering playing cards, all of which featured designs similar in tone to what the image artist had set. She improvised as a means of coping with the unexpected. Whilst the unexpected event had initially made Alf also feel anxious and uncertain, at the same time it evoked a reaction to overcome the challenge it had created. He did not let things be "so" but turned around his mood of feeling threatened, to treat it as a test of character which perhaps fed-back to his reflexive monitoring of himself - elsewhere known as one's "ego". 


\section{A Date with Microsoft}

Andy had gone to great lengths to prevent any technical surprises during the course of the war game project. His continuous reflexive monitoring of working contexts over time had taught him to do so, given the number of frustrating projects he had been involved with. Also, his monitoring of other contexts such as the games industry had given him a stock of knowledge of games which he mobilized in order to reach agreement with the customer over the details of the game. However, when his overseas client created a business opportunity with Microsoft, this unexpected occurrence evoked feelings of frustration in him. However, he rationalized his mood with the idea of Microsoft, a "deity" of software development, reviewing his work. This inspired him into a flurry of impromptu activity including calling on resources to lend "polish" to his work, i.e. he began to focus on the bells and whistles of game. For example, he contacted Arthurian Legend's musician in Italy to courier a $\mathrm{CD}$ of samples. However, embedding sound into the game unintentionally presented problems for him. Through trial and error he resolved these "bugs" and drawing on skills of bricolage put together a working demo of the game. Again, the appeal of "something greater" had made Andy shift gear and put aside the scripts of action he had created which he intended to lend order and stability to his project.

\section{The Lead Programmer Leaves}

The unexpected resignation of Richard led to a break down in the working procedures of the developers as he had been largely responsible for their upkeep. His had set an example to the others in the team. However, in his absence, these practices were not sustained at any level in the organization, including management. John and Andy mused that Alf probably did not have time to follow the procedures. The resignation event affected Mac's mood; he was not willing to exercise his agency anymore, he seemed inert and his reflexive monitoring of his contexts had broken down. His way of coping with the unforeseen was to retreat altogether from teamwork. On the other hand, John responded differently. Since he shared the lead programmer's skill set, John took over Richard's programming responsibilities. John became stressed at the thought of increased workload and perhaps the possibility of failure drove him to turn his mood into one of determination and single-mindedness. To cope he exercised his agency by improvising through rules and resources. For example, instead of programming from scratch he made use of an established game engine "Torque", and the phrase "keep it simple stupid" as guiding principle. The rules and resources that underpinned his capability as an agent were perhaps acquired though his continuous monitoring of his contexts; he had first come across the Torque game engine a few years ago. Unlike Mac, John's reflexive monitoring of others and his contexts heightened.

\section{Integrating the Findings}

To begin the gradual process of theorizing through gradual bottom-up abstraction, we now strip down the interpretations of the above narratives and draw together the elements common to each, in terms of; who was affected by the event, the event itself, the emotions, the event provoked in those affected and the subsequent impromptu acts of those affected. We assemble these in table 2.

We now assign a descriptive code to (i) “event", (ii) "moods provoked" and (iii) "acts provoked" (the columns in table 2) to interpret their essential meaning: (i) the events seem to have staff or stakeholder resignation in common, with the exception of "a date with Microsoft", which we interpret as an opportunity, (ii) these events provoked negative moods of anxiety and frustration, however in most cases these turned around into positive moods of single-mindedness, or desire for independence or freedom, (iii) these moods 
Table 2. Consequences of unforeseen events

\begin{tabular}{|c|c|c|c|c|}
\hline Who & Event & Moods provoked & Acts provoked & Id \\
\hline Alf & Jacky and team walk out $\rightarrow$ & $\begin{array}{l}\text { Anxiety, but turns to } \\
\text { Single-mindedness } \rightarrow\end{array}$ & $\begin{array}{l}\text { Modification of an existing game } \\
\text { concept }\end{array}$ & A1 \\
\hline Alf & Jacky and team walk out $\rightarrow$ & Single-mindedness $\rightarrow$ & $\begin{array}{l}\text { Assumes leadership role, assembles } \\
\text { team }\end{array}$ & A2 \\
\hline Gayle & $\begin{array}{l}\text { Loss of } \\
\text { image artist } \rightarrow\end{array}$ & $\begin{array}{l}\text { Anxiety, but turns to single-mindedness } \\
\rightarrow\end{array}$ & $\begin{array}{l}\text { Referring to visual materials, trying to } \\
\text { become self-reliant }\end{array}$ & A3 \\
\hline Alf & $\begin{array}{l}\text { Loss of } \\
\text { image artist } \rightarrow\end{array}$ & $\begin{array}{l}\text { Desperation, but turns to single-mind- } \\
\text { edness } \rightarrow\end{array}$ & $\begin{array}{l}\text { Global talent hunt, contacting global } \\
\text { gatekeepers }\end{array}$ & A4 \\
\hline Andy & A date with Microsoft $\rightarrow$ & $\begin{array}{l}\text { Frustration, but realizes an opportunity } \\
\text { for recognition of his work, i.e. turns to } \\
\text { self-actualizing. }\end{array}$ & $\begin{array}{l}\text { Reprioritizes game features for devel- } \\
\text { opment }\end{array}$ & A5 \\
\hline Mac & $\begin{array}{l}\text { Lead programmer's resigna- } \\
\text { tion } \rightarrow\end{array}$ & Inertia, giving up $\rightarrow$ & Retreat from team work to self & A6 \\
\hline John & $\begin{array}{l}\text { Lead programmer's resigna- } \\
\text { tion } \rightarrow\end{array}$ & $\begin{array}{l}\text { Stress, loss of enjoyment, but turns to } \\
\text { Single-mindedness } \rightarrow\end{array}$ & $\begin{array}{l}\text { Leveraging technological tools for } \\
\text { productivity }\end{array}$ & A7 \\
\hline
\end{tabular}

in turn provoked a variety of improvisations experimenting, searching, leveraging, seizing and reprioritizing (refer to table 3). Some of these smack of creativity, e.g. experimenting and searching. Drawing on this, we can broadly say that staff or stakeholder resignations initially provoked moods of anxiety and frustration in the developers, but this then evoked a desire and mood for independence or freedom, which in turn provoked creative improvisations.

\section{DISCUSSION AND IMPLICATIONS}

Section five demonstrated the unforeseen challenges faced by agents in their game development process, particularly relating to staff or stakeholder resignations, theirmoody responses, and how these constrained and enabled their improvisations, i.e. the process by which they regulated their emotions in a volatile context. Most in our study were able to regulate their emotions effectively, to use negative emotions to provoke positive action (e.g. table 2, codes A1, A2, A3, A4, A5, A7). This seemed to constitute part of their agency; their capability to act. We therefore extend Giddens' stratification

Table 3. Typology of improvised acts

\begin{tabular}{|l|l|l|}
\hline Id & Acts provoked & Type of impromptu act \\
\hline A1 & Modification of an existing game concept & Leveraging \\
\hline A2 & Assumes leadership role, assembles team & Seizing \\
\hline A3 & Referring to visual materials, trying to become self-reliant & Searching \\
\hline A4 & Global talent hunt, contacting global gatekeepers & Searching \\
\hline A5 & Reprioritizes game features for development & Reprioritizing \\
\hline A6 & Retreat from team work to self & Introspecting \\
\hline A7 & Leveraging technological tools for productivity & Leveraging \\
\hline
\end{tabular}


model of the agent in to account for this emotional dimension of human agency (see Figure 1).

\section{Conceptualization}

Figure 3 is a conceptualization of the process by which agents regulate their moods; how they rationalize and act upon them in a volatile context. We now offer an interpretation of this model. Starting from the top of the model: as developers reflexively monitor their contexts they become aware of unforeseen events, such as staff or stakeholder resignations. They then interpret (as per appraisal theory) and rationalize the meaning of the event in their context. As they do so this affects their motivation for action and produces negative emotions of anxiety and frustration - these are the unintended consequences of the actions or unforeseen events that originate in the context. Now we follow the model from the bottom back to the top: these emotions become part of the unacknowledged conditions for a developer's action or improvisation. In their practical consciousness the agent's will or motivation to overcome negativity leads them to reinterpret and re-rationalize the meaning of the (resignation) event in their context, which in turn produces a positive mood of and desire for freedom. The developer then adjusts their reflexive monitoring and leads to a number of improvisations such as experimenting, searching, leveraging, seizing and reprioritizing. These improvisations evoke creativity and learning. This then is the process by which agents/ developers regulate their moods and cope with unexpected challenging events; emotion-mediated improvisation. The model (figure 1)also provides a conceptualization of the detailed elements of the emotional journeys of game developers, which broadly fall into three characteristics: emotion, action and events.

\section{Implications}

This extended stratification model has implications for our knowledge of how emotions mediate the way game developers improvise through the unexpected; the process by which they regulate their moods in volatile contexts. According to our conceptualization, rationalization and interpretation play an important role in this process. According to appraisal theory, in the words of Wang and Ahmed (2002), emotions are reactions to a certain situation based on the person's interpretation. Therefore, by modifying an interpretation or the meaning of an event in context, we may positively influence the emotions of an agent and the way they are harnessed for improvisation. This modifying of interpretation is evocative of sensemaking: "sensemaking is about authoring as well as reading" (Weick 1995:p7). By affecting the sensemaking process then, so we perhaps can influence the mood response of developers or the way they regulate their emotions. This has implications for our knowledge of approaches to software development. It is not sufficient to have approaches such as agile methods that emphasize cooperation and embrace change (Beck 1999). We also need approaches that actively incorporate the sensemaking of change, of the unforeseen, so

Figure 3. Emotion-mediated improvisation: an extended stratification model

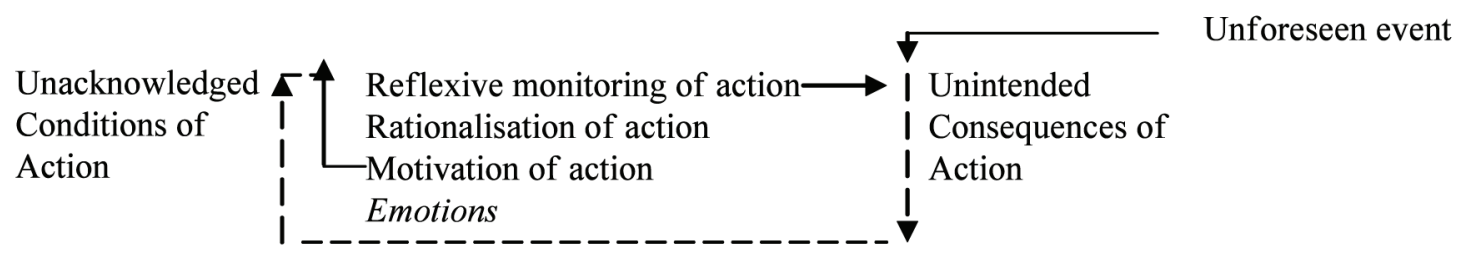


as to influence moods, their regulation and their offspring improvisations.

Our findings and theory also have implications for practicing managers in creative software development. In order to effectively manage developers' moods when faced with volatile contexts and disruptive events, managers need to consider means of influencing developers' interpretations of events. This is perhaps a matter of charismatic leadership. Managers need to be able to reinterpret for themselves the negative moods produced by such events as staff or stakeholder "walkouts", before then helping those under their charge make positive sense of them - help developers to regulate their moods, so as to produce creative improvisations. This does not mean wiping out a negative response to an event, but rather leveraging it and turning it into a positive one. This is consistent with Bagozzi (2003), who shows how negative moods can produce positive effects, such as embarrassment provoking efforts to repair relationships. Furthermore, during volatile times developers should be encouraged to open up their social working contexts and continuously monitor them instead of shrinking, so as to build their stock of resources; resources of a material, technological and social nature that may be invoked at the appropriate time; being prepared; readiness through reflexive monitoring. If developers remain close to their screens however they may be assuming safety in blindness, particularly in SMEs such as CGS where the manager may be away and incumbents have to fend for themselves or improvise in his or her absence. In volatile situations then, management should encourage searching, seizing, reprioritizing and leveraging of resources (refer to table 3 ).

\section{CONCLUSION}

This chapter has elucidated the emotional journeys of game developers by revealing their processes of socioemotional work by drawing on Giddens' stratification model of the agent. Game developers by-and-large exhibited capabilities to regulate their emotions in the face of volatile, disruptive events. By regulate, we mean the way game developers rationalize and act upon their emotions, i.e. how they improvise when they encounter and interpret unanticipated challenges. Briefly, our conceptualization theorizes that through their reflexive monitoring, game developers interpret the meanings of unexpected events, which affects their motivation for action and produces negative emotions. These emotions constitute unacknowledged conditions for action or improvisation, but through an agent's will or motivation to overcome negativity, they re-interpret the meaning of the event, which in turn produces a positive emotion and desire for 'freedom'. This produces a number of improvisations such as experimenting, searching, leveraging, seizing and reprioritizing. These improvisations evoke creativity and learning. Therefore, since emotions are reactions based on a person's interpretation, by modifying an interpretation or the meaning of an event in context, we may positively influence the emotions of the agent and the way they are harnessed for improvisation. This modifying of interpretation is evocative of sensemaking (Weick 1995). By affecting the sensemaking process (Brown, Stacey et al, 2008) we can influence the mood response of developers or the process by which they regulate their emotional journeys. The implication for our knowledge of software development is that it is not sufficient to have approaches that emphasize cooperation and embrace change (Beck 1999). Such approaches should also actively incorporate sensemaking with respect to change and unforeseen events, so as to influence the regulation of consequential negative moods, and subsequently leverage these moods for positive and creative improvisation. 


\section{REFERENCES}

Amabile, T. M., Barsade, S. G., Mueller, J. S., \& Staw, B. M. (2005). Affect and Creativity at Work. Administrative Science Quarterly, 50, 367-403. doi:10.2189/asqu.2005.50.3.367

Baba, Y., \& Tschang, F. T. (2001). Product development in Japanese TV game software: The case of an innovative game. International Journal of Innovation Management, 5(4), 487-515. doi:10.1142/S1363919601000464

Bagozzi, R. P. (2003). Positive and Negative Emotions in Organizations. In Cameron, K. S., Dutton, J. E., \& Quinn, R. E. (Eds.), kPositive Organizational Scholarship: foundations of a new discipline. K. S. Cameron. San Francisco, CA: Berrett-Koehler Publishers.

Bailyn, J. (2002). Who makes the rules? Using Wittgenstein in Social Theory. Journal for the Theory of Social Behaviour, 32(3). doi:10.1111/14685914.00189

Bartel, C. A., \& Saavedra, R. (2000). The Collective Construction of Work Group Moods. Administrative Science Quarterly, 45, 197-231. doi: $10.2307 / 2667070$

Beck, K. (1999). Extreme programming explained: embrace change. Boston, MA: Addison-Wesley Longman Publishing Co., Inc.

Bjork, S., Holopainen, J., Ljungstrand, P., \& Akesson, K. P. (2002). Designing Ubiquitous Computing Games - A Report from a Workshop Exploring Ubiquitous Computing Entertainment. Personal and Ubiquitous Computing, 6, 443-458. doi:10.1007/s007790200048

Brown, A. B., Stacey, P. K., \& Nandhakumar, J. (2008). Making sense of sensemaking narratives. Human Relations, 61(8). doi:10.1177/0018726708094858
Callahan, J. L., \& McCollum, E. E. (2002). Conceptualizations of Emotion Research in Organizational Contexts. Advances in Developing Human Resources, 4(1), 4-21. doi:10.1177/1523422302004001002

Cassell, P. (1993). The Giddens Reader. London: Macmillan.

Cheok, A. D., Yang, X., Ying, Z. Z., Billinghurst, M., \& Kato, H. (2002). Touch-Space: Mixed Reality Game Space Based on Ubiquitous, Tangible, and Social Computing. Personal and Ubiquitous Computing, 6, 430-442. doi:10.1007/ s007790200047

Ciborra, C. U. (1999). Notes on improvisation and time in organizations. Accounting. Management \& Information Technology, 9(2), 77-94. doi:10.1016/S0959-8022(99)00002-8

Ciborra, C. U. (2002). The Labyrinths of Information: Challenging the Wisdom of Systems. Oxford: Oxford University Press.

Clanton, C. (1998). An Interpreted Demonstration of Computer Game Design. ACM CHI 98 conference summary on Human factors in computing systems. Los Angeles, CA: ACM Press.

Cross, N. (1994). Engineering design methods. Chichester, UK: John Wiley.

Curtis, B., Krasner, H., \& Iscoe, N. (1988). AField Study of the Software Design Process for Large Systems. Communications of the ACM, 31(11). doi: $10.1145 / 50087.50089$

Cusumano, M.A., \& Yoffie, D. B. (1999). Software development on Internet time. IEEE Computer, $32(10), 60-69$.

Diener, E. (2000). The Science of Happiness and a Proposal for a National Index. The American Psychologist, 55(1), 34-43. doi:10.1037/0003066X.55.1.34 
Ellis, C. (1995). Emotional and Ethical Quagmires in returning to the field. Journal of Contemporary Ethnography, 24(1), 68-98. doi:10.1177/089124195024001003

Fineman, S. (2003). Understanding Emotion at Work. London: Sage Publications.

Frijda, N. H. (1988). The Laws of Emotion. The American Psychologist, 349-358. doi:10.1037/0003-066X.43.5.349

George, J. M., \& Zhou, J. (2007). Dual Tuning in a Supportive Context: joint Contributions of Positive Mood, Negative Mood, and Supervisory. AcademyofManagement Journal, 50(3), 605-622.

Giddens, A. (1984). The Constitution of Society: Outline of the Theory of Structure. Berkeley, CA: University of California Press.

Giddens, A. (1993). New rules of sociological method: a positive critique of interpretative sociologies (2nd ed.). Cambridge, UK: Polity Press.

Goleman, D., Boyatzis, R., \& McKee, A. (2002). The New Leaders: Transforming the art of leadership into the science of results. Time Warner.

Guinan, P. J., Cooprider, J. G., \& Faraj, S. (1998). Enabling Software Development Team Performance During Requirements Definition: A Behavioral Versus Technical Approach. Information Systems Research, 9(2). doi:10.1287/isre.9.2.101

Highsmith, J. (2002). Agile Software Development Ecosystems. Boston, MA: Addison-Wesley.

Hirschheim, R., Klein, H., \& Lyytinen, K. (1995). Information systems development and data modeling: conceptual and philosophical foundations. Cambridge, UK: Cambridge University Press.

Holmström, J. (2001). Virtual Communities as Platforms for Product Development - an interpretive case study of Customer Involvement in Online Game Development. In Proceedings of the 22nd International Conference on Information Systems (ICIS 2001). New Orleans, Louisiana.
Huizinga, J. (1970). Homo Ludens. London: Granada Publishing Ltd.

Humphrey, W. S., Snyder, T. R., \& Willis, R. R. (1991). Software Process Improvement at Hughes-Aircraft. IEEE Software, 8(4), 11-23. doi:10.1109/52.300031

Johnson, D., \& Wiles, J. (2003). Effective affective user interface design in games. Ergonomics, 46, 1332-1345. doi:10.1080/00140130310001 610865

Jones, M., \& Karsten, H. (2003). Review: structuration theory and information systems research. Research Papers in Management Studies - Judge Institute of Management, University of Cambridge, WP 11/2003.

Jones, M. R., \& Walsham, G. (1992). The limits of the knowable: organizational and design knowledge in systems development. In Kendall, K. E., Lyytinen, K., \& DeGross, J. I. E. (Eds.), The Impact of Computer Supported Technologies on Information Systems Development. Amsterdam. Amsterdam: North-Holland.

Kaneva, K., \& Sugiyama, T. (1998). Design and simulation of interactive 3D computer games. Computers \& Graphics, 22(2-3), 281-300. doi:10.1016/S0097-8493(98)00038-7

Kruchten, P. (1996). A Rational Development Process. Crosstalk, 9(7), 11-16.

Lastowka, F. G., \& Hunter, D. (2004). The Laws of the Virtual Worlds. California Law Review, 92, 3-73. doi:10.2307/3481444

Levi-Strauss, C. (1966). The Savage Mind. Chicago, IL: University of Chicago Press.

Lofland, J. (1995). Analytical ethnography: features, failings and futures. Journal of Contemporary Ethnography, 24(1), 30-67. doi:10.1177/089124195024001002 
Nandhakumar, J., \& Avison, D. E. (1999). The Fiction of Methodological Development, a Field Study ofInformation Systems. Information Technology \& People, 12(2). doi:10.1108/09593849910267224

Nandhakumar, J., \& Jones, M. (1997). Designing in the Dark: The Changing User-Developer Relationship in IS Development. In Proceedings of the Eighteenth International Conference on Information Systems, Atlanta, Georgia, United States.

Nelson, K. (2005). Exploring Emotions during ERP Adoption: A Stakeholder Analysis. In Proceedings of the 38th Annual Hawaii International Conference on System Sciences. HICSS '05.

Newman, M., \& Noble, F. (1990). User Involvement as an Interaction Process: A Case Study. Information Systems Research, 1(1), 89-113. doi:10.1287/isre.1.1.89

Nutt, D., \& Railton, D. (2003). The Sims: Real Life as Genre. Information Communication and Society, 6,577-592. doi:10.1080/1369118032000163268

Orlikowski, W. J. (1996). Improvising Organizational Transformation over Time: A Situated Change Perspective. Information Systems Research, 7(1), 63. doi:10.1287/isre.7.1.63

Parkinson, B., Fischer, A. H., \& Manstead, A. S. R. (2005). Emotions and social relations: Cultural, Group, and Interpersonal Processes. New York: Psychology Press.

Paulk, M. C. (2001). Extreme Programming from a CMM Perspective. Raleigh: XP Universe.

Robey, D., \& Markus, M. L. (1984). Rituals in Information System Design. Management Information Systems Quarterly, 8(1), 5-15. doi:10.2307/249240

Rosen, M. (1991). Coming to terms with the field: understanding and doing organizational ethnography. Journal of Management Studies, 28(1), 1-24. doi:10.1111/j.1467-6486.1991.tb00268.x
Rouse III, R. (1999). Everything Old is New Again: Remaking ComputerGames. Computer Graphics.

Sawyer, S. (2001). Effects of Conflict on Packaged Software Development Team Performance. Information Systems Journal, 11(2), 155-178. doi:10.1046/j.1365-2575.2001.00100.x

Schaeffer, J., \& Jaap van den Herik, H. (2002). Games, computers, and artificial intelligence. Artificial Intelligence, 134, 1-7. doi:10.1016/ S0004-3702(01)00165-5

Scherer, K. R., Walbott, H. G., \& Summerfield,A. B. (1986). Experiencingemotion: A cross-cultural study. Cambridge: Cambridge University Press.

Strauss, A. L., \& Corbin, J. (1998). Basics of Qualitative Research-techniques and procedures for developing grounded theory. Thousand Oaks, CA: Sage Publications, Inc.

Truex, D., Baskerville, R., \& Travis, J. (2000). Amethodical systems development: the deferred meaning of systems development methods. Accounting. Management \& Information Technology, 10, 53-79. doi:10.1016/S0959-8022(99)00009-0

Tschang, F. (2007). Balancing the Tensions Between Rationalization and Creativity in the Video Games Industry. Organization Science, 18(6), 989-1005. doi:10.1287/orsc.1070.0299

Vosburg, S. K. (1998). The Effects of Positive and Negative Mood on Divergent-Thinking Performance. Creativity Research Journal, 11.

Walsham, G. (1993). Interpreting IS in Organizations. Chichester, UK: John Wiley.

Wang, C. L., \& Ahmed, P. K. (2002). Emotion: the missing partofsystemsmethodologies. Kybernetes, 32(9/10), 1283. doi:10.1108/03684920310493251

Wastell, D. G. (1996). The fetish of technique: methodology as a social defence. Information Systems Journal, 6(1), 25-40. doi:10.1111/j.1365-2575.1996.tb00003.x 
Weick, K. (1995). Sensemaking in organizations. Thousand Oaks, CA: Sage.

Williams, R. B., \& Clippinger, C. A. (2002). Aggression, competition and computer games: computer and human opponents. Computers in Human Behavior, 18, 495-506. doi:10.1016/ S0747-5632(02)00009-2

\section{ENDNOTES}

1 http://www.develop-online.net/news/31696/ Hundreds-spill-the-beans-on-industrysdirty-secret-crunch

2 E.g. Stacey, P.K. (2010) Quality of Design Life in Singapore, Develop Magazine, 2010. 